\title{
Sustainability Key Performance Indicators in Islamic Banking Sectors of Malaysia and Pakistan: A Scale Based Evidence
}

\author{
Haseeb Ur Rahman ${ }^{1 *}$, Muhammad Zahid ${ }^{2}$, Muhammad Asif ${ }^{3}$, Zabeeh Ullah ${ }^{4}$ \\ ${ }^{1}$ Institute of Management Sciences, University of Science and Technology, Bannu, Pakistan \\ 2, 3, 4 Department of Management Sciences, City University of Science and Information Technology, \\ Peshawar, Pakistan
}

\section{Keywords \\ Sustainability \\ Key Performance \\ Indicators \\ Reporting Index \\ Malaysia \\ Pakistan}

Received: 26 February 2020

Accepted: 02 May 2020

\begin{abstract}
The marvelous development in the Islamic banking necessitates sustainable practices in the emerging industry. This study intends to ascertain the most followed or usual sustainability key performance indicators (KPIs) in the Islamic banking industry of Malaysia and Pakistan. For developing the sustainability KPIs index, the study follows the systematic steps as highlighted by prior such studies. The index composed of 109 items in 7 main sections of sustainability reporting adapted to collect data through content analysis for 21 Islamic banks from both the countries for the year 2016. Despite significant heterogeneity among the Islamic banks of the two countries, it is found that they show good compliance with the sustainability indicators. Though the Islamic banking industry of Pakistan is small than that of Malaysia, but still it is good in reporting sustainable practices except for environment and product responsibility, where the latter has an edge over the former. The study contributes a theoretical deliverable i.e. sustainability KPIs index for the Islamic banking industry through testing it with data from 21 Islamic banks from Malaysia and Pakistan. The findings could be significant for practitioners, regulators, policymakers, and especially the Islamic banking industry of both countries.
\end{abstract}

KAUJIE Classification: H47, L25

JEL Classification: C43, G21, L25, Z12

(c) 2020 JIBM. All rights reserved.

\section{INTRODUCTION}

There is tremendous growth in the Islamic financial services industry as the overall asset value had been reached USD 1.5 trillion by 2017 as reported by the Islamic Financial

\footnotetext{
*Corresponding author: Haseeb Ur Rahman Javed

${ }^{\dagger}$ Email: drhaseeb@ustb.edu.pk
} 
Services Board: Stability Report 2016 (Islamic Financial Services Board (IFSB), 2016). It necessitates measures for sustainable practices in the Islamic banking industry. Moreover, from the Islamic reporting perspective, the stakeholders expect that social concerns should be a principal agenda of disclosures in annual reports. Accordingly, Islamic banks are supposed to be more translucent and sustainable in their disclosure practices. However, in contrast, the studies reported that sustainability practices particularly in the Islamic banking industry are less matured and not fully implemented as compared to conventional banks (World Bank Group \& IRTI, 2016). Among the reasons, there are no comprehensive Key Performance Indicators (KPIs) available for the reporting of sustainability-related practices in the Islamic banking industry. Though some studies attempted to fill this gap including Alvarado-Herrera, Bigne, Aldas-Manzano, and Curras-Perez, (2017), Amran et al. (2017), Jan, Marimuthu, and Pisol, (2019), Moisescu (2015), Rehman et al. (2020), but still space and motivation exist for further research in the area. For instance, despite focusing on sustainability, the studies ignored the integrated reporting mechanisms. Some authors propose to investigate the level of sustainability practices in Islamic banking industries (Rehman et al., 2020). Similarly, in another study, the authors further propose the investigation of other sustainability dimensions such as Governance and Strategic Commitments (GSM), Shari`‘ah Compliance (SC), Employees Welfare and Development (EWD), Ethics and Human Rights (EHR), and Product Responsibility (PR) in the Islamic banking industry (Jan et al., 2019). Hence, keeping in view the above discussion, there is a need for a comprehensive index covering all the above aspects for acceptable and comprehensive sustainability reporting. Henceforth, the current study tries to fill this gap by identifying and developing the sustainability reporting KPIs for the Islamic banking industry. The study also attempts to cover the shortcomings of the previous studies by finding answers to the research questions: i) What are the key performance and reporting indicators for sustainability practices among the Islamic banking industry, and ii) What is the trend of sustainability key performance and reporting indicators among the Islamic banking institutions?

To answer, the current study selected the Islamic banking industries of Malaysia and Pakistan for the year 2016. Two major countries like Malaysia and Pakistan could be considered as the best sample for research in Islamic banking practices and performance. The period 2016 of the study could be considered recent as most of the reports of the selected Islamic banks were available online. The data collection procedure of sustainability KPIs is based on Global Reporting Initiative (GRI) framework 2016 and Sharī'ah compliance manuals of both Malaysia and Pakistan. As theoretical deliverables, the study produces a sustainability KPIs index for Islamic banking institutions of Malaysia and Pakistan. The study unveils the factual tendency of these KPIs in the two countries that could be worthy for the practitioners, regulators, and policymakers in the future. The study is also valuable for Islamic banks of both countries to align their sustainability practices reporting with international standards and recommendations.

The paper is further structured as the literature review from a theoretical perspective, followed by the research methodology, findings, discussion, and conclusion of the study. 


\section{THEORETICAL FRAMEWORK}

The literature review here aims to ascertain the theoretical underpinning/perspective for the study. For decades, scholars have been stressing over the positive role of business towards society. This role led to the consensus for rethinking about Corporate Social Responsibility (CSR). The role further manifested when the world started to face new environmental challenges such as global warming. To face these challenges, the traditional CSR agenda has now transformed into business sustainable practices with a focus on social, economic, and environmental issues. The classical school of thought about business responsibility represented by Friedman (1970) assumed that corporations had the only obligation to make a legitimate profit. Also, it assumed that CSR activities cause extra cost and hence affect firms' sustainability and performance (Pinkston \& Carroll, 1996). However, some other scholars enumerated a variety of firms' responsibilities towards their stakeholders. Moreover, these scholars also cascaded many categories of stakeholders and their responsibilities (Donaldson \& Preston, 1995; Freeman, 1984). Given that, the current study underpins the theoretical framework based on stakeholder theory as against the shareholders' or shareholders' primacy theory. The theory postulates that the business organizations need to manage positive relationships with the stakeholder for their claims (Perez, Martinez, \& Rodriguez del Bosque, 2013). The cases in focus here are the banking institutions, and the welfare they extend or supposed to extend for the betterment of all stakeholders through their actions. These stakeholders included employees, customers, shareholders, society, the environment, and regulatory bodies. The stakeholders' theory impeccably suits to the banking industry for their sustainability practices and benefitting all their stakeholders. Traditionally, the banking industry took good care of the interests of shareholders only to overcome the problems of financial exclusion. However, nowadays, the banking institutions are encouraged to consider sustainability practices into their strategic agenda to focus on social, environmental, and economic sustainability (Alvarado-Herrera et al., 2017; Dissanayake, Tilt, \& Xydias-Lobo, 2016).

\section{Context of Islamic Banking in Malaysia and Pakistan Sustainability-Items generation and identification}

The Islamic banking industry has received substantial introspection and pushes from various stakeholders to peruse operations ethically and responsibly. However, some previous studies noted that the social responsiveness of the Islamic banks has negative implications on their overall performance and reputation (Rehman et al., 2020). Still, the stakeholders now a day are increasingly demanding social responsibility and sustainability practices of the firm. Among others, the investors are also focusing on sustainable practices of the firms where they invest their funds. Subsequently, the management of the Islamic banking industry is in tremendous pressure to adopt sustainability practices in their routine operations (Khan, Islam, Fatima, \& Ahmed, 2011). However, as discussed earlier, the management is encountered with the problems of adopting comprehensive and accepted sustainability indicators for the industry. Some studies have attempted to fill this gap. Nevertheless, they also leftover some unexplored aspects creating avenues for further research. Thus, this study fills the evident 
gap by developing the sustainability reporting KPIs for the Islamic banking industry. The study also attempts to cover the shortcomings of the previous literature.

Corporate disclosures disseminate appropriate and important information to existing and prospective stakeholders, who can affect or be affected by the company's current and future operations/performance (Ho \& Wong, 2001). Moreover, these disclosures serve two purposes for the stakeholders; first, to evaluate the current state of an organization's social, environmental, and economic activities, and second, to communicate these disclosures to the stakeholders (Global Reporting Initiative (GRI), 2013). Sustainability disclosures are voluntary both in Malaysia and Pakistan (Aliyu, Hassan, Mohd Yusof, \& Naiimi, 2017; State Bank of Pakistan (SBP), 2018b, 2018a). Voluntary disclosures that may have a substantial influence on the decision-making of the users are the information not mandatory to report. It is the discretion of the firms or their management to voluntarily determine both the quality and quantity of these disclosures or their reporting ( Meek, Roberts, \& Gray, 1995).

To achieve the objective, this study focuses on identifying the most followed disclosures of Islamic banking sustainability practices. Accordingly, the study utilizes a sustainability disclosure index - an instrument to gauge the reported information under a specific disclosure by a particular entity against a list of certain items or information (Marston \& Shrives, 1991). The disclosures index has been widely used in prior studies as a proxy to identify and measure the level of firms' disclosures (Madi, 2012).

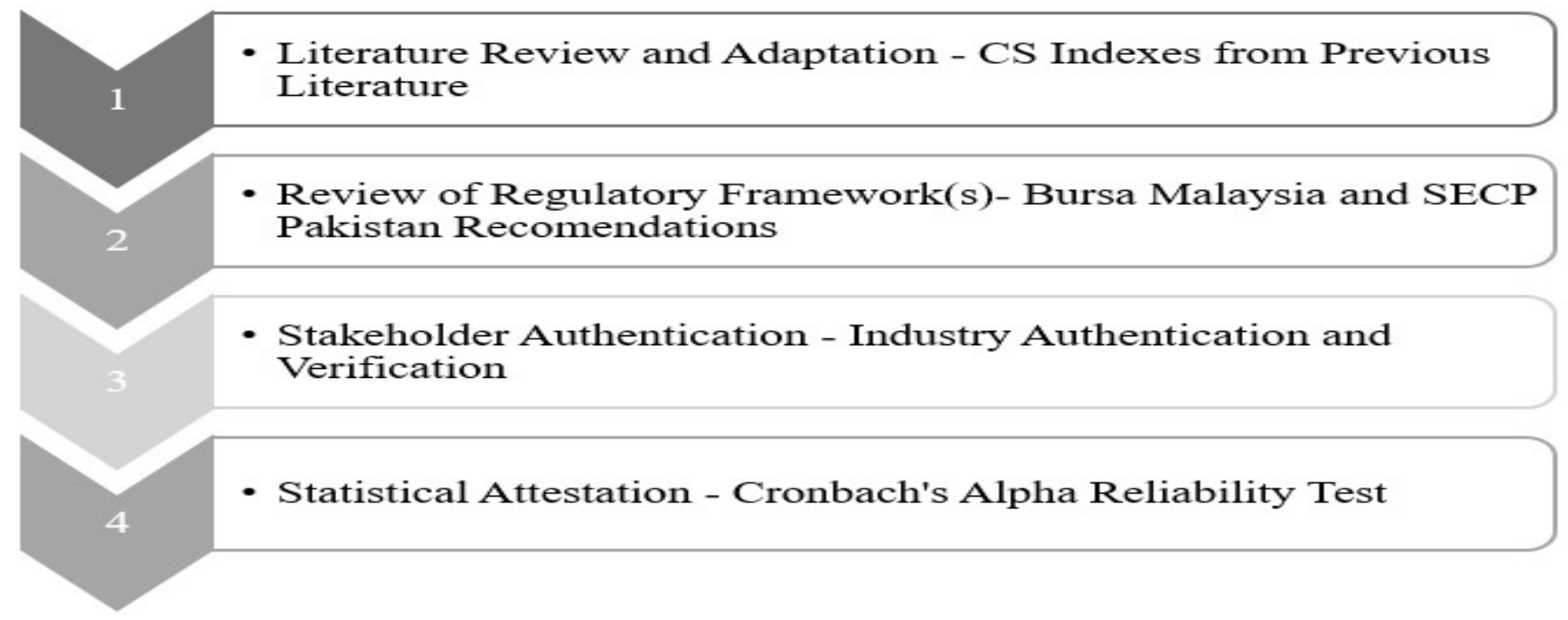

FIGURE 1. Steps for Corporate Sustainability (CS) disclosure index development

A four steps approach depicted in Figure 1 was followed to develop sustainability disclosure index for the Islamic banking industry as recommended by previous authors (Anas, Abdul Rashid, \& Annuar, 2015; Dissanayake et al., 2016; Kansal, Joshi, \& Batra, 2014; Othman, Darus, \& Arshad, 2011; Zahid et al., 2019). Firstly, an extensive literature review was employed to identify sustainability indicators. A review of the literature is beneficial to identify, adopt or adapt sustainability indicators and determine the level of their reliability to be used as a proxy for firm sustainability practices ( Bonilla-Priego, Font, \& PachecoOlivares, 2014; Lozano \& Huisingh, 2011; Roca \& Searcy, 2011). For the development of this 
index, the current study focused on sustainability indicators based on the GRI sustainability reporting guidelines ( Global Reporting Initiative (GRI), 2013) and recommendations for the Islamic banking industry. The "GRI sustainability reporting guidelines were developed as a way of helping organizations to report on their environmental, social and economic performance increasing their accountability, through the implementation of the transparency, inclusiveness, suitability, completeness, relevance, sustainability context, accuracy, neutrality, comparability, clarity, and timeliness principles" (Bonilla-Priego et al., 2014). Moreover, GRI reporting is considered as a helpful tool to gain international confidence, the trustworthiness of corporate reporting, and positive perception among the broader spectrum of stakeholders (Clarkson, Li, Richardson, \& Vasvari, 2008; Global Reporting Initiative (GRI), 2013; Othman et al., 2011). To examine the level of sustainability practices, most of the previous studies used sustainability disclosure index based on GRI which has produced consistent and substantiated results across many countries, like the United States of America, Mexico, Malaysia, Australia, Hong Kong, New Zealand, Sweden, Spain, the United Kingdom, China, Kenya, Denmark, Bangladesh, Italy, Pakistan, Malaysia, and Turkey, etc. (Alvarado-Herrera et al., 2017; Amran et al., 2017; Jan et al., 2019; Moisescu, 2015; Rehman et al., 2020).

After the identification and listing of the items of sustainability disclosures in the second step, these disclosures were randomly checked with the selected annual reports of the Islamic banks from both Malaysia and Pakistan. The existing literature related to CS practices mainly focused on the existing indexes developed from past studies to measure sustainability practices (Lozano \& Huisingh, 2011; Roca \& Searcy, 2011) without considering the country-specific context and industry requirements. However, the current study uses sustainability indicators which are based on the five dimensions approach of sustainability practices proposed and specifically recommended for the Islamic banking industry (Anas et al., 2015; Bursa Malaysia, 2006), as discussed below.

\section{Environmental sustainability}

The environmental aspect of sustainability addresses the impact of a firm on both the living and non-living natural systems which include land, air, water, and ecosystems, among others. It also accounts for the firms' impact on inputs (energy and water) and outputs (emissions, effluents, and waste). Biodiversity, transport, product pertaining impacts along with environmental compliance and expenditures are those topics covered under the subject (Global Reporting Initiative (GRI), 2013,).

\section{Social sustainability}

The social dimension of sustainability addresses the impacts of firms on the social systems of the area where they are located or operate. Labor Practices and Decent Work, Human Rights, Society, and Product Responsibility are the key areas of interest under the subject (Global Reporting Initiative (GRI), 2013).

\section{Governance and strategic commitment}

Transparency and governance structure, among others, are the characteristics of the firm 
crucial for ensuring liability, responsibility, and accountability of the bodies and individuals. These Standard Disclosures explain the establishment of the highest governance body to support a firm's purpose and its alignment with economic, environmental, and social dimensions (Global Reporting Initiative (GRI), 2013 ).

In the third step, this index was verified from the various industries as recommended by the previous studies (Madi, 2012; Othman et al., 2011). After identification of the most followed items of sustainability practices (including environmental, social, and governance \& strategic commitments), a reliability test was conducted using Cronbach's alpha score for all the items to assess the reliability/internal consistency of the disclosure index. The value of Cronbach's alpha of 109 items is 0.947 (combined), 0.949 for Malaysia, and 0.899 for Pakistan. Moreover, there was no item excluded from the index consequent upon zero variance.

TABLE 1

Reliability and Scale Statistics

\begin{tabular}{llllll}
\hline \hline Cronbach's alpha & Cronbach's alpha & Items & Mean & Variance & Data \\
\hline 0.947 & 0.942 & 100 & 0.571 & 0.082 & Combine \\
0.949 & 0.945 & 100 & 0.543 & 0.82 & Malaysia \\
0.899 & 0.896 & 100 & 0.471 & 0.06 & Pakistan \\
\hline \hline
\end{tabular}

The final score of sustainability indicators consists of 109 items (Exhibits in Appendix A), including environmental, social, and governance \& strategic commitments categories. Cronbach's alpha score reported in Table 1 is below the recommended threshold (Anas et al., 2015; Kansal et al., 2014).

\section{METHODOLOGY}

This study relied on the published annual reports of the Islamic banks in Malaysia and Pakistan for the year 2016. The content analysis method of data collection is less expensive and less obtrusive as compared to some other data collection methods. It has been used frequently and applied in studies related to CS practices (Delai \& Takahashi, 2013). The content analysis has been defined as "a technique for gathering data that consists of codifying qualitative information in anecdotal and literary form into categories to derive quantitative scales of varying levels of complexity" (Abbott \& Monsen, 1979) cited in (Said, Zainuddin, \& Haron, 2009). The study relied on the un-weighted scoring approach as recommended by previous studies (Eccles, Loannou, \& Sarafeim, 2013; Esa \& Ghazali, 2012; Gao \& Bansal, 2013; Haniffa \& Cooke, 2005; Nazli, Ahmad, Salat, \& Haraf, 2013). In the unweighted scoring method, a dichotomous procedure is applied, where disclosure is assigned a value 1 if an item is disclosed in the report of a company, and 0 otherwise. For recording each disclosure, the CS disclosures index -Appendix A was used. Based on the CS disclosure index, a total score for each company was measured as CSP $=\sum$ di Where $\mathrm{d}=1$ if the sustainability item is disclosed; and $\mathrm{d}=0$ if the item is not disclosed and $\mathrm{i}$ represents the year(s). The highest score of the content is implied as the highest performance (Singal, 2013). 
A list of the selected Islamic banks from both the countries (Malaysia and Pakistan) is given in Table 2.

TABLE 2

List of Islamic Banks

\begin{tabular}{lll}
\hline \hline SNo & Name of the Bank & Country \\
\hline 1 & Affin Islamic Bank Berhad & Malaysia \\
2 & Al Rajhi Banking Investment Corporation (Malaysia) Berhad & Malaysia \\
3 & Alliance Islamic Bank Berhad & Malaysia \\
4 & AmBank Islamic Berhad & Malaysia \\
5 & Asian Finance Bank Berhad & Malaysia \\
6 & Bank Islam Malaysia Berhad & Malaysia \\
7 & Bank Muamalat Malaysia Berhad & Malaysia \\
8 & CIMB Islamic Bank Berhad & Malaysia \\
9 & HSBC Amanah Malaysia Berhad & Malaysia \\
10 & Hong Leong Islamic Bank Berhad & Malaysia \\
11 & Kuwait Finance House (Malaysia) Berhad & Malaysia \\
12 & Maybank Islamic Berhad & Malaysia \\
13 & OCBC Al-Amin Bank Berhad & Malaysia \\
14 & Public Islamic Bank Berhad & Malaysia \\
15 & RHB Islamic Bank Berhad & Malaysia \\
16 & Standard Chartered Saadiq Berhad & Malaysia \\
17 & Bank Islami Pakistan & Pakistan \\
18 & Islamic commercial bank (Al Baraka) & Pakistan \\
19 & Meezan Bank & Pakistan \\
20 & Bank Alfalah Limited & Pakistan \\
21 & Dubai Islamic Bank Pakistan Ltd & Pakistan \\
\hline \hline
\end{tabular}

\section{RESULTS}

Table 3 reports descriptive statistics of sixteen Malaysian Islamic banks regarding sustainability practices for 2016. It combines range, minimum, maximum, mean, standard deviation, skewness, and kurtosis. SPSS Compute command employed to combine each category namely Governance and Strategic Commitments (GSM), Sharī'ah Compliance (SC), Employees Welfare and Development (EWD), Environmental (ENV), Ethics and Human Rights (EHR), Product Responsibility (PR) and Social (SOC) sustainability. For GSM, the Malaysian Islamic banks reported a minimum of 6, maximum 18, with a mean value of 13.24. Similarly, Pakistani Islamic banks reported a minimum of 12, a maximum 17, and a mean value of 15.40 for GSM. As compared to Malaysian Islamic banks, Pakistani banks report higher mean value and hence lead in GSM. In SC category minimum values are 4 and 8 while maximum values are 11 and 10 with mean values of 8.31 and 9.00 for Malaysian and Pakistani Islamic banks respectively. These statistics also suggest that the mean value for Pakistani banks is higher than that of Malaysia. For EWD, EHR, and SOC the mean value 
of Islamic banks in Pakistan is higher than those of Malaysia. However, in the ENV and PS categories, the Malaysian Islamic banks have higher mean values than that of Pakistani banks. The overall results reveal that heterogeneity exists between the Islamic banks of the two countries regarding reporting sustainability practices. However, for environmental and product responsibility, Malaysian banks have an edge over their Pakistani counterparts.

TABLE 3

Descriptive Statistics

\begin{tabular}{|c|c|c|c|c|c|c|c|c|c|c|}
\hline \multicolumn{11}{|c|}{ Descriptive Statistics of Malaysia } \\
\hline & $\mathrm{N}$ & Range & Min & Max & Mean & S.D & Skewness & STD. Error & Kurtosis & STD. Error \\
\hline GSM & 16 & 12 & 6 & 18 & 13.875 & 3.242 & -0.811 & 0.564 & 0.775 & 1.091 \\
\hline $\mathrm{SC}$ & 16 & 7 & 4 & 11 & 8.312 & 2.272 & -0.754 & 0.564 & -0.26 & 1.091 \\
\hline EWD & 16 & 7 & 7 & 14 & 10.5 & 2.191 & 0.261 & 0.564 & -0.997 & 1.091 \\
\hline Env & 16 & 14 & 4 & 18 & 10 & 4.575 & 0.339 & 0.564 & -1.037 & 1.091 \\
\hline HER & 16 & 10 & 1 & 11 & 5.125 & 2.604 & 0.62 & 0.564 & 0.285 & 1.091 \\
\hline PS & 16 & 15 & 3 & 18 & 11.812 & 3.371 & -0.842 & 0.564 & 2.374 & 1.091 \\
\hline SOC & 16 & 12 & 0 & 12 & 3 & 4 & 1.45 & 0.564 & 0.509 & 1.091 \\
\hline \multicolumn{11}{|c|}{ Descriptive Statistics of Pakistan } \\
\hline & $\mathrm{N}$ & Range & Min & Max & Mean & S.D & Skewness & STD. Error & Kurtosis & STD. Error \\
\hline GSM & 5 & 5 & 12 & 17 & 15.4 & 2.3 & -1.016 & 0.913 & -1.007 & 2 \\
\hline $\mathrm{SC}$ & 5 & 2 & 8 & 10 & 9 & 0.7 & 0 & 0.913 & 2 & 2 \\
\hline EWD & 5 & 5 & 11 & 16 & 13.6 & 2.4 & -0.473 & 0.913 & -3.086 & 2 \\
\hline Env & 5 & 8 & 2 & 10 & 5.2 & 3.11 & 0.933 & 0.913 & 0.762 & 2 \\
\hline EHR & 5 & 2 & 13 & 15 & 13.6 & 0.89 & 1.258 & 0.913 & 0.312 & 2 \\
\hline PS & 5 & 2 & 7 & 9 & 8 & 1 & 0 & 0.913 & -3 & 2 \\
\hline SOC & 5 & 3 & 10 & 13 & 11.6 & 1.516 & -0.315 & 0.913 & -3.081 & 2 \\
\hline \multicolumn{11}{|c|}{ Descriptive Statistics of Combined } \\
\hline & $\mathrm{N}$ & Range & Min & Max & Mean & S.D & Skewness & STD. Error & Kurtosis & STD. Error \\
\hline GSM & 21 & 12 & 0 & 12 & 3.5238 & 3.85511 & 1.085 & 0.501 & -0.302 & 0.972 \\
\hline $\mathrm{SC}$ & 21 & 7 & 4 & 11 & 8.4762 & 2.01542 & -1.015 & 0.501 & 0.653 & 0.972 \\
\hline EWD & 21 & 7 & 7 & 14 & 10.7619 & 2.07135 & 0.016 & 0.501 & -1.042 & 0.972 \\
\hline Env & 21 & 14 & 4 & 18 & 10.8571 & 4.39643 & -0.074 & 0.501 & -1.164 & 0.972 \\
\hline EHR & 21 & 10 & 1 & 11 & 5.8095 & 2.61952 & 0.026 & 0.501 & -0.676 & 0.972 \\
\hline PS & 21 & 15 & 3 & 18 & 12.2381 & 3.04803 & -1.198 & 0.501 & 3.422 & 0.972 \\
\hline SOC & 21 & 12 & 0 & 12 & 3.5238 & 3.85511 & 1.085 & 0.501 & -0.302 & 0.972 \\
\hline
\end{tabular}

\section{DISCUSSION AND CONCLUSION}

To answer the first research question i.e. what are the key performance and reporting indicators for sustainability practices between the Islamic banking industries, the study selected full-fledged Islamic banks from two Islamic countries-Malaysia and Pakistan. The data was collected from the annual reports of these banks. A total of 21 annual reports were utilized in the study combining 16 from Malaysia and 5 from Pakistan. After applying for a comprehensive literature review, 100 indicators were identified under seven major headings. The identified indicators were then verified through a relevant test for reliability. 
The results disclosed and validated the identified indicator for sustainability, as the most followed by the Islamic banks of both countries. To answer the second research question of the study i.e. what is the trend of sustainability key performance and reporting indicators among the Islamic banking industry, the descriptive statistical inquiry provided evidence for a noteworthy heterogeneity regarding sustainability practices in Islamic banks of the two countries. Despite a limited number of Islamic banks in Pakistan, they reported better sustainability practices than Malaysian banks except for environment and product responsibility, where the latter has edge over the former. The study identified the most followed sustainability indicators among the Islamic banking industry of Malaysia and Pakistan. Hence, it contributed a theoretical deliverable i.e. sustainability KPIs index for the Islamic banking industry through testing it with data from 21 Islamic banks from Malaysia and Pakistan. The findings could be significant for practitioners, regulators, policymakers, and especially the Islamic banking industry of both countries. For further robustness, the index of the current study should be further tested in the longitudinal nature of data. Moreover, it is also recommended to test the index in other countries where the Islamic banking industry exists, is expanding, or has prospects.

\section{REFERENCES}

Abbott, W. F., \& Monsen, R. J. (1979). On the measurement of corporate social responsibility: Self-reported disclosures as a method of measuring corporate social involvement. Academy of Management Journal, 22(3), 501-515. doi: https://doi.org/10.5465/255740

Aliyu, S., Hassan, M. K., Mohd Yusof, R., \& Naiimi, N. (2017). Islamic banking sustainability: A review of literature and directions for future research. Emerging Markets Finance and Trade, 53(2), 440-470. doi: https://doi.org/10.1080/1540496X.2016.1262761

Alvarado-Herrera, A., Bigne, E., Aldas-Manzano, J., \& Curras-Perez, R. (2017). A scale for measuring consumer perceptions of corporate social responsibility following the sustainable development paradigm. Journal of Business Ethics, 140(2), 243-262. doi: https://doi.org/10.1007/s10551-015-2654-9

Amran, A., Fauzi, H., Purwanto, Y., Darus, F., Yusoff, H., Zain, M. M., Malianna, D., Naim, A., \& Nejati, M. (2017). Social responsibility disclosure in Islamic banks: A comparative study of Indonesia and Malaysia. Journal of Financial Reporting and Accounting, 15(1). doi: https://doi.org/http://dx.doi.org/10.1108/MRR-09-2015-0216

Anas, A., Abdul Rashid, H. M., \& Annuar, H. A. (2015). The effect of award on CSR disclosures in annual reports of Malaysian PLCs. Social Responsibility Journal, 11(4), 831-852. doi: https://doi.org/10.1108/SRJ-02-2013-0014

Bonilla-Priego, M. J., Font, X., \& Pacheco-Olivares, M. D. R. (2014). Corporate sustainability reporting index and baseline data for the cruise industry. Tourism Management, 44, 149-160. doi: https://doi.org/10.1016/j.tourman.2014.03.004

Bursa Malaysia. (2006). Corporate Social Responsibility (CSR) framework for Malaysian public listed companies. Retrieved from: https://www.scribd.com/document/76636360/CsrWriteup 
Clarkson, P. M., Li, Y., Richardson, G. D., \& Vasvari, F. P. (2008). Revisiting the relation between environmental performance and environmental disclosure: An empirical analysis. Accounting, Organizations and Society, 33(4-5), 303-327. doi: https://doi.org/10.1016/j.aos.2007.05.003

Delai, I., \& Takahashi, S. (2013). Corporate sustainability in emerging markets: Insights from the practices reported by the Brazilian retailers. Journal of Cleaner Production, 47, 211-221. doi: https://doi.org/10.1016/j.jclepro.2012.12.029

Dissanayake, D., Tilt, C., \& Xydias-Lobo, M. (2016). Sustainability reporting by publicly listed companies in Sri Lanka. Journal of Cleaner Production, 129(2016), 169-182. doi: https://doi.org/10.1016/j.jclepro.2016.04.086

Donaldson, T., \& Preston, L. E. (1995). The stakeholder theory of the corporation: Concepts, evidence, and implications. Academy of Management Review, 20(1), 65-91. doi: https://doi.org/10.5465/amr.1995.9503271992

Eccles, R. G., Loannou, L., \& Sarafeim, G. (2013). The Impact of corporate sustainability on organizational processes and performance. Management Science, 60(11), 1-46. doi: https://doi.org/http://dx.doi.org/10.1287/mnsc.2014.1984

Esa, E., \& Ghazali, N. A. M. (2012). Corporate social responsibility and corporate governance in Malaysian government-linked companies. Corporate Governance: The International Journal of Business in Society, 12(3), 292-305.

doi: https://doi.org/10.1108/14720701211234564

Freeman, R. E. (1984). Stakeholder Theory of the modern corporation. strategic management: A stakeholder approach. Cambridge, UK: Cambridge University Press. doi: ttps://doi.org/10.1017/CBO9781139192675

Friedman, M. (1970). A Friedman doctrine: The social responsibility of business is to increase its profits. The New York Times Magazine, 13, 32-33.

Gao, J., \& Bansal, P. (2013). Instrumental and integrative logics in business sustainability. Journal of Business Ethics, 112(2), 241-255. doi: https://doi.org/10.1007/s10551-012$1245-2$

Global Reporting Initiative (GRI). (2013). G4 global reporting initiative guidelines: Reporting principles and standard disclosures. Retrieved from: doi: https://cutt.ly/4sWr8Wf

Haniffa, R. M., \& Cooke, T. E. (2005). The impact of culture and governance on corporate social reporting. Journal of Accounting and Public Policy, 24(5), 391-430. doi: https://doi.org/10.1016/j.jaccpubpol.2005.06.001

Ho, S. S. M., \& Wong, K. S. (2001). A study of corporate disclosure practices and effectiveness in Hong Kong. Journal of International Financial Management and Accounting, 12(1), 75-101.

Islamic Financial Services Board (IFSB). (2016). Islamic financial services industry: Stability report 2016. Islamic Financial Services Board, Kuala Lumpur, Malaysia.

Jan, A., Marimuthu, M., \& Pisol, M. (2019). The nexus of sustainability practices and financial performance: from the perspective of Islamic banking. Journal of Cleaner Production, 1(2), 1-25. doi: https://doi.org/10.1016/j.jclepro.2019.04.208 
Kansal, M., Joshi, M., \& Batra, G. S. (2014). Determinants of corporate social responsibility disclosures: Evidence from India. Advances in Accounting, 30, 217-229. doi: https://doi.org/10.1016/j.adiac.2014.03.009

Khan, H., Islam, M. A., Fatima, J. K., \& Ahmed, K. (2011). Corporate sustainability reporting of major commercial banks in line with GRI: Bangladesh evidence. Social Responsibility Journal, 52(2), 82-109. doi: https://doi.org/10.1108/17471111111154509

Lozano, R., \& Huisingh, D. (2011). Inter-linking issues and dimensions in sustainability reporting. Journal of Cleaner Production, 19(2-3), 99-107. doi: https://doi.org/10.1016/j.jclepro.2010.01.004

Madi, H. K. (2012). Audit committee effectiveness and voluntary disclosure in Malaysia: Pre and post introduction of the revised Malaysian code on corporate governance 2007 (Ph.D. dissertation). Universiti Utara Malaysia, Changlun, Malaysia.

Marston, C. L., \& Shrives, P. J. (1991). The use of disclosure indices in accounting research: A review article. The British Accounting Review, 23(3), 195-210. doi: https://doi.org/10.1016/0890-8389(91)90080-L

Meek, G. K., Roberts, C. B., \& Gray, S. J. (1995). Factors influencing voluntary annual report disclosures by US, UK and continental European multinational corporations. Journal of International Business Studies, 26(3), 555-572.

Moisescu, O. I. (2015). Development and validation of a measurement scale for customers' perceptions of corporate social pesponsibility. Management $\mathcal{E}$ Marketing, 13(2), 311332.

Nazli, N., Ahmad, N., Salat, A., \& Haraf, A. (2013). Environmental disclosures of Malaysian property development companies: Towards legitimacy or accountability? Social Responsibility Journal, 9(2), 241-258. doi: https://doi.org/10.1108/SRJ-10-2011-0090

Othman, S., Darus, F., \& Arshad, R. (2011). The influence of coercive isomorphism on corporate social responsibility reporting and reputation. Social Responsibility Journal, 7(1), 118-135. doi: https://doi.org/10.1108/17471111111114585

Perez, A., Martinez, P., \& Rodriguez del Bosque, I. (2013). The development of a stakeholder-based scale for measuring corporate social responsibility in the banking industry. Service Business, 7(3), 459-481. doi: https://doi.org/10.1007/s11628-012-0171-9

Pinkston, T. S., \& Carroll, A. B. (1996). A retrospective examination of CSR orientations: Have they changed? Journal of Business Ethics, 15(2), 199-206. doi: https://doi.org/10.1007/BF00705587

Rehman, Z. U., Zahid, M., Rahman, H. U., Asif, M., Alharthi, M., Irfan, M., \& Glowacz, A. (2020). The impact of corporate social responsibility disclosure on the financial performance of Islamic banking industry in Pakistan. Sustainability, 12(3302), 1-18. doi: https://doi.org/10.3390/su12083302

Roca, L. C., \& Searcy, C. (2011). An analysis of indicators disclosed in corporate sustainability reports. Journal of Cleaner Production, 20(1), 103-118.

doi: https://doi.org/10.1016/j.jclepro.2011.08.002

Said, R., Zainuddin, Y. H., \& Haron, H. (2009). The relationship between corporate social responsibility disclosure and corporate governance characteristics in Malaysian public 
listed companies. Social Responsibility Journal, 5(2), 212-226.

doi: https://doi.org/10.1108/17471110910964496

State Bank of Pakistan (SBP). (2018a). Islamic banking bulletin. Islamic Banking Department, State Bank of Pakistan, Karachi, Pakistan.

State Bank of Pakistan (SBP). (2018b). State bank of Pakistan.

Retrieved from: http://www.sbp.org.pk/departments/ibd.htm

Singal, M. (2013). The link between firm financial performance and investment in sustainability initiatives. Cornell Hospitality Quarterly, 55(1), 19-30.

doi: https://doi.org/10.1177/1938965513505700

World Bank Group, \& IRTI. (2016). Global report on Islamic finance: A catalyst for shared prosperity? Islamic Development Bank Group, Jeddah, Saudi Arabia.

Zahid, M., Rahman, H. U., Muneer, S., Butt, B. Z., Isah-Chikaji, A., \& Memon, M. A. (2019). Nexus between government initiatives, integrated strategies, internal factors and corporate sustainability practices in Malaysia. Journal of Cleaner Production, 241, 118329. doi: https://doi.org/10.1016/j.jclepro.2019.118329 


\section{APPENDIX}

\section{Index for Sustainability Reporting Indicators in Islamic Banking}

Governance and Strategic Commitment

1. Focus on maximizing stakeholders returns

2. Operating within the Sharī'ah principles

3. Appreciating the stakeholders and the customers

4. Commitment to engage only in permissible financing activities

5. Name of the board of directors

6. Position holding the board of directors

7. Shareholding of the board of directors

8. Remuneration of the board of directors

9. Head of the audit committee observing the AAIOFI standards

10. Profile for the board of directors

11. Various sub-committees exist

12. Name and position of the sub-committees exist

13. Any internal committee for the customer's grievance mechanism

14. Academic qualification of the management team

15. Members of the sub-committee of the management team

16. Remuneration committee

17. Any human resource management committee

18. Proper functional Research and development

\section{Sharī'ah Compliance}

1. Names of the SSB members

2. Qualification of the SSB members

3. Remuneration of the members

4. Proper report signs by the members

5. Numbers of meetings held

6. Examination of the documents based on the sample

7. Examination of all the documents

8. No defect in the products

9. Report defects in the products

10. Report of the SSB

11. Nature of unlawful transactions

12. Certification of the distribution of profits and loss complying with principles of Sharī'ah

13. Zakāh calculated according to the Sharī'ah

\section{Social Sustainability}

1 Funding to organizations that provide benefits to the community for social equity

2 Fostering strong links with the community/public service

3. Creating job opportunities

4. Amount spent in community activities 
5. Participation in government-sponsored social activities

6. Zakāh payment-monetary

7. Zakāh payment-beneficiaries

8. SSB attestation that sources and uses of $z a k \bar{a} h$ are according to Sharí'ah

9. SSB attestation that Zakāh has been computed according to Sharī'ah

10. Qard hassan-monetary

11. Q ard hassan-beneficiaries

12. Șadqah-monetary

13. Sadqah-beneficiaries

14. Regular performance and career development report

15. Strategy formulation and decision-making support to the top management standardize training curriculum

16. Database management

\section{Employees Welfare and Development}

1. Equal opportunities policy

2. Employees' welfare

3. Ensuring diversity

4. Any promotion mechanism/policy for the employees

5. Training: Sharī'ah awareness

6. Training: professional skill

7. Encouraging talent

8. Keeping the policy of international labor standard

9. Reward for employees

10. Employees' appreciation

11. Any health, education facilities for the employee

12. Any promotion mechanism/policy for the employees

13. Any online or offline grievances mechanism for the employees

14. Gender equality

15. Measures for the staff safety

16. Occupational health and education facilities to employees

17. Equal remuneration for men and women

\section{Ethics and Human Rights}

1. Non-discriminative policies irrespective of age, sex, and ethnicity

2. Policies regarding sexual harassment

3. Dealing with the legal items only

4. Paying the taxes to the government

5. Comprehensive code of conduct

6. Whether the bank prevents corruption and other financial irregularities

7. Protects human rights

8. Whether provides accurate information to the customers

9. Provides secure transactions

10. The proper security mechanism for employees and customers 
11. Whether following rules and regulations prescribed by the state bank of Pakistan

12. Whether observing the labor laws practices

13. Supplier human rights assessment

14. Gender equality

15. Anti-corruption and anti-money laundering policies

16. Proper code of ethics for the employees

17. Proper code of ethics for the internal auditors

18. Human rights grievances mechanism

\section{Product and Services}

1. Basis of Sharī'ah concept on the new product

2. Introduction of SSB approved new products

3. Definition of the new product

4. Safe and Secure internet facilities available for banking

5. No investment in non-permissible products

6. Fair dealing with those in the supply chain

7. Secure internet banking facility provided to the customer/stakeholders

8. Any customer grievances mechanism

9. Nature of the unlawful transaction

10. Promotion of research and development

11. Customers secrecy and privacy

12. Customers health and safety

\section{Environmental Sustainability}

1. Introduction of the green product

2. Glossary/definition of the green product

3. The amount of donation in environmental awareness

4. Financing in any project which may lead to environmental damage

5. Initiatives to mitigate environmental impacts of product and services

6. Focus on risk-based corrective actions

7. Environmental grievances mechanism

8. Investment in environmentally friendly products

9. Energy conservation

10. Measures for providing clean water to the stakeholders

11. Water conservation

12. Biodiversity

13. Measures for reduction of greenhouse gases

14. Measures to ensure pollution-free transport to the employees and stakeholders

15. Supplier environmental assessment 